\title{
Antineoplastic activity of acetone semicarbazone (ASC) against Ehrlich ascites carcinoma (EAC) bearing mice
}

\author{
J.A. Khanam ${ }^{*}$, M. F. Islam ${ }^{1}$, M. Jesmin ${ }^{2}$ and M. M. Ali ${ }^{2}$ \\ ${ }^{l}$ Department of Biochemistry and Molecular Biology, Faculty of Science, University of Rajshahi, Rajshahi, Bangladesh. \\ 2 Department of Applied Chemistry and Chemical Technology, Faculty of Engineering, University of Rajshahi, Rajshahi, Bangladesh.
}

Revised: 28 January 2009; Accepted: 10 February 2010

\begin{abstract}
Acetone semicarbazone (a Schiff base) has been synthesized and characterized. Its antineoplastic activity has been studied against Ehrlich ascites carcinoma (EAC) cells in Swiss albino mice by monitoring parameters like tumor weight, survival time, tumor cell growth inhibition and haematological characteristics. It was found that the compound at dose $2.0 \mathrm{mg} / \mathrm{kg} /$ day i.p (intra peritoneal) significantly decreases tumor weight, increases life span and reduces tumor cell growth rate in comparison to those of EAC bearing mice. The compound also alters the depleted haematological parameters like red blood cells (RBC), white blood cells (WBC), haemoglobin $(\mathrm{Hb}) \%$ and differential counts (i.e. lymphocytes, neutrophils, monocytes) of EAC bearing mice towards normal. The compound enhances the number of macrophages in normal mice. The toxic effects of the compound on the host are not very high and the host recovers gradually towards normal within a few days after treatment. The compound can therefore be considered as a new potent antitumor agent. The efficiency is more or less comparable to that of a standard drug like bleomycin $(0.3 \mathrm{mg} / \mathrm{kg} /$ day, i.p. $)$.
\end{abstract}

Keywords: Acetone semicarbazone, antineoplastic activity, EAC cells, haematology.

\section{INTRODUCTION}

Cancer continues to represent the second largest cause of mortality in the world and claims over six million lives every year ${ }^{1}$. An extremely promising strategy for treatment of cancer today is chemotherapy. Schiff bases have been reported ${ }^{2-11}$ to have antibacterial, antifungal, antiviral, anti-inflammatory, anti-tubercular, antiHIV, antileprosy and herbicidal activities. Because these bases appear to have such wide applications, many investigators are now focusing attention on the possibility of developing chemotherapeutic agents from Schiff bases. Schiff bases of semicarbazone and their derivatives also possess potential anticancer activities. Anticancer activity of hydroxysemicarbazide against L1210 murine leukemia cells showed higher inhibitory effect than hydroxyurea ${ }^{12}$. Some thiosemicarbazones have been shown to have anticancer and antiviral activities $^{13}$. Nickel (II) complexes of semicarbazone derivatives showed potent anticancer activity against MCF-7 cell lines ${ }^{14}$. Semicarbazones, thiosemicarbazones and acetyl-hydrazones of phthalimide, o-benzosulfinide, napthalimide and diphenimide demonstrated potent cytotoxicity against different cancer cell lines ${ }^{15}$. The antitumoric activity of pyridine-2-carboxaldehyde thiosemicarbazones and a series of di-2-pyridyl ketone thiosemicarbazone ligands have also been reported in literature ${ }^{16,17}$. Most of these semicarbazones possess large structures and are mostly insoluble in common solvents. Much difficulty has been encountered to solubilize them for use. As acetone semicarbazone is a water soluble compound, it was selected for evaluation of its antineoplastic activity against Ehrlich ascites carcinoma (EAC) cells in Swiss albino mice.

\section{METHODS AND MATERIALS}

a) Chemicals and reagents: All chemicals and reagents used throughout the investigation were of reagent grade.

b) Synthesis of acetone semicarbazone (ASC): The procedure described by $\operatorname{Vogel}^{18}$ was used for synthesis of this compound. Semicarbazide $(1.0 \mathrm{~g})$ and Na-acetate $(1.50 \mathrm{~g})$ were mixed in a reagent bottle and dissolved in $10 \mathrm{~mL}$ of pure distilled water. Acetone $(1.0 \mathrm{~mL})$ was added to the mixture. The resulting solution was shaken vigorously for several minutes and allowed to stand for a few minutes untill a white crystalline product was 
obtained. The precipitate was washed with a little distilled water, recrystallized from aqueous medium and dried in an oven at $105^{\circ} \mathrm{C}$. The melting point of the compound was found to be $187^{\circ} \mathrm{C}$. The compound was stored in a desiccator over silica gel.

c) Characterization of the compound (ASC): The formation and purity of the compound was verified with the help of infra red (IR) spectra (given in Figure 1) and also by comparing the melting point of the compound with the literature value ${ }^{19}\left(187^{0} \mathrm{C}\right)$. The principal new bond formed was $-\mathrm{N}=\mathrm{C}<$. Other characteristic active groups present in the compound were $-\mathrm{NH}_{2}>\mathrm{C}=\mathrm{O},-\mathrm{CH}_{3}$ etc. All these groups were ascertained from IR spectral analysis. The peak in the region 1670-1606 $\mathrm{cm}^{-1}$ had appeared due to the formation of $\mathrm{C}=\mathrm{N}$ bond. This peak was broader than expected because the peak was coupled with other peaks due to $\mathrm{C}=\mathrm{O}$ stretching at $1690-1650 \mathrm{~cm}^{-1}$ and $\gamma_{\mathrm{N}-\mathrm{H}}$ (bending) (1650-1620) from the $\mathrm{H}_{2} \mathrm{~N}-\mathrm{CO}$ - group present at one side of the molecule. The $\gamma_{\mathrm{N}-\mathrm{H}}$ (stretching) from the $-\mathrm{NH}_{2}$ end appeared at $3400-3300 \mathrm{~cm}^{-1}$. The two methyl groups were present on the other side of the molecule peaks at 1448 and $1417 \mathrm{~cm}^{-1}\left[\gamma_{\mathrm{C}-\mathrm{H}}\right.$ bending]. The other peaks appearing in the spectrum were due to the combined effect of the whole molecule.

d) Animals: Adult Swiss albino male mice (20-25 g) were used throughout this study. They were obtained from the International Center for Diarrheal Diseases Research, Bangladesh (ICDDRB). Animals were fed with standard mouse-pellets (collected from ICDDRB) and water was given ad libitum.

e) Tumour cells: Ehrlich Ascites Carcinoma (EAC) cells were obtained with the courtesy of Indian Institute for Chemical Biology (IICB), Kolkata, India and maintained by weekly i.p. inoculation of $10^{5}$ cells/mouse in the laboratory.

f) Ethical clearance: The protocol used in this study for the use of mice as animal models for cancer research was approved by the University Animal Ethical committee.

g) Determination of median lethal dose $\left(L D_{50}\right)$ : The $\mathrm{LD}_{50}$ value was determined following conventional methods ${ }^{20}$. The test compound was dissolved in distilled water and injected intraperitoneally to 6 groups of mice (each containing $\mathrm{n}=6)$ at different doses $(10,20,30,40$, 50 and $60 \mathrm{mg} / \mathrm{kg}$ ). LD $_{50}$ was evaluated by recording mortality after $24 \mathrm{~h}$.

h) Cell growth inhibition: In vivo tumor cell growth inhibition was carried out by the method as described in a previous study ${ }^{21}$. For this study, 5 groups of mice (6 in each group) were used. For therapeutic evaluation $14 \times 10^{5}$ cells/mouse were inoculated into each group

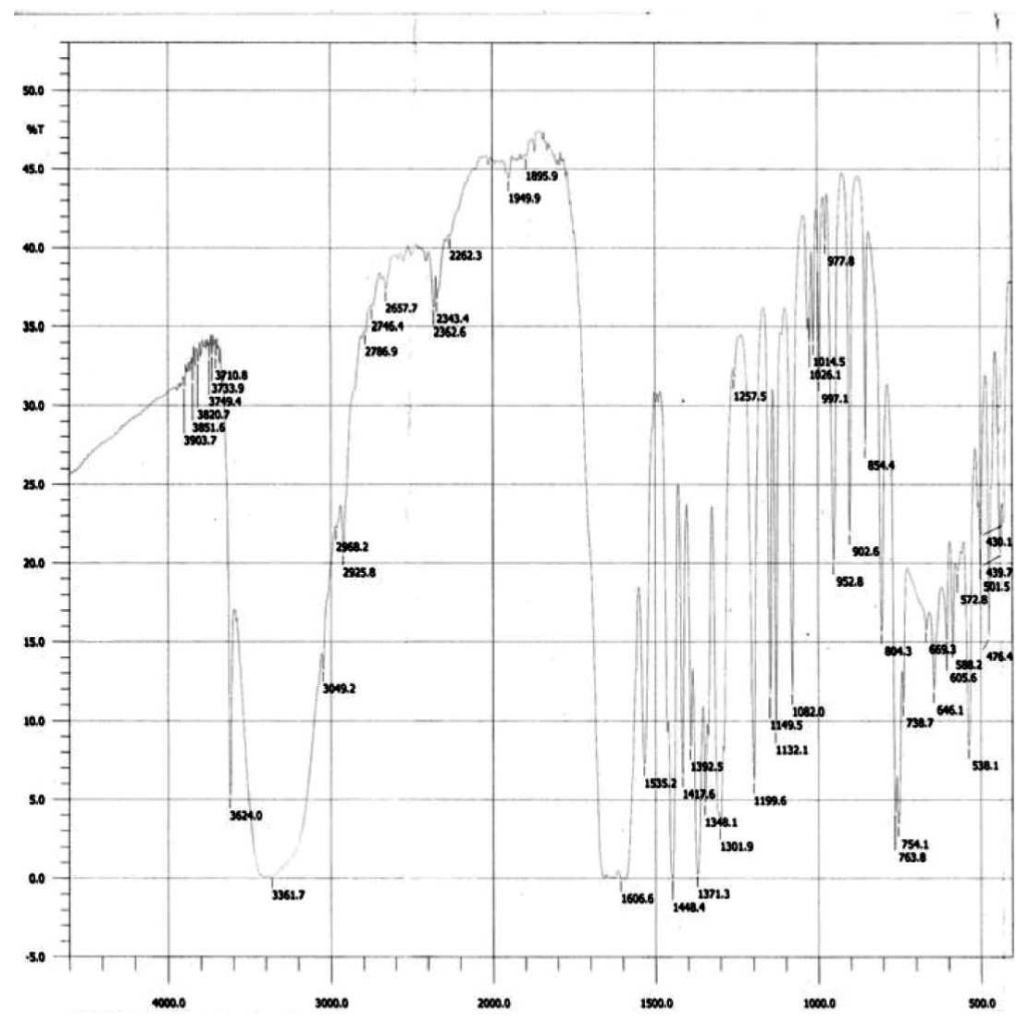

Figure 1: IR spectra of acetone semicarbazone 


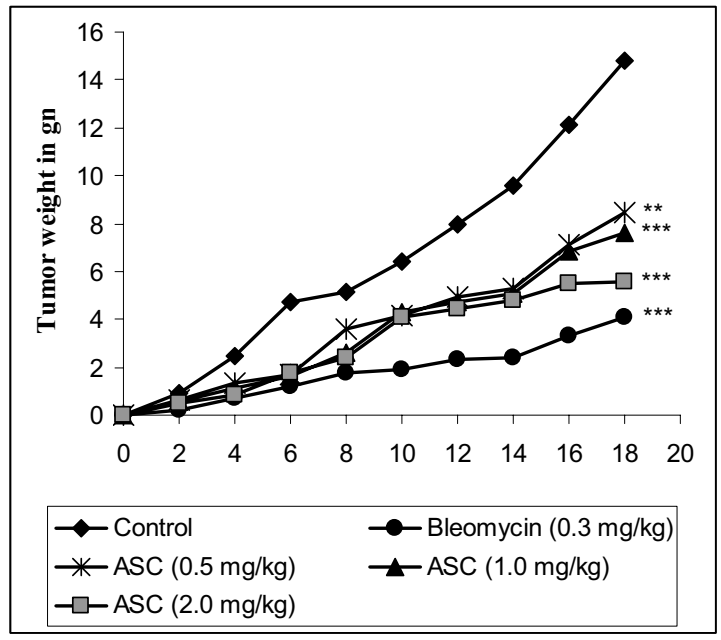

Figure 2: Effect of ASC at the dose $0.5 \mathrm{mg} / \mathrm{kg}$ (i. p.), $1 \mathrm{mg} / \mathrm{kg}$ (i. p.) and $2 \mathrm{mg} / \mathrm{kg}$ (i. p.) on tumor weight in mice

Numbers of mice in each experiment were 6. The results are shown in mean \pm SEM and compared with control, where significant values are, ${ }^{*} \mathrm{p}<0.05,{ }^{* *} \mathrm{p}<0.01$ and ${ }^{* * *} \mathrm{p}<0.001$.

of mice on the first day. Treatment was started after $24 \mathrm{~h}$ of tumor inoculation and continued for $5 \mathrm{~d}$. Group 1 - 3 received the test compound at the doses $0.5 \mathrm{mg} / \mathrm{kg}$, $1.0 \mathrm{mg} / \mathrm{kg}$ and $2.0 \mathrm{mg} / \mathrm{kg}$ respectively, per day per mouse. In each case the volume of the test solution injected (i.p.) were $0.1 \mathrm{~mL} /$ day per mouse. Group 4 received bleomycin $(0.3 \mathrm{mg} / \mathrm{kg}$, i.p.) and group 5 was treated with the vehicle (normal saline) and was considered as untreated control. The mice were sacrificed on the $6^{\text {th }}$ day after transplantation and tumor cells were collected by repeated intraperitoneal wash with $0.9 \%$ saline. Viable tumor cells per mouse of the treated group were compared with those of the control.

The cell growth inhibition was calculated by using the formula,

$$
\% \text { Cell growth inhibition }=\left(1-\frac{\mathrm{Tw}}{\mathrm{CW}}\right) \times 100
$$

Where, $\mathrm{Tw}=$ mean number of tumor cells of the treated group of mice and $\mathrm{CW}=$ mean number of tumor cells of the control group of mice.

i) Bioassay of EAC cells (Transplantation ability of $E A C$ cells): The effect of ASC on transplantability of EAC cells was carried out by the method described in the literature ${ }^{22}$. In this experiment 2 groups of mice $(n=4)$ were inoculated with $115 \times 10^{5}$ EAC cells. Group 1 was treated with the test compound at the dose of $2.0 \mathrm{mg} / \mathrm{kg}$ (i.p.) for 5 consecutive days and group 2 served as the control. On day 7, tumor cells from the mice were

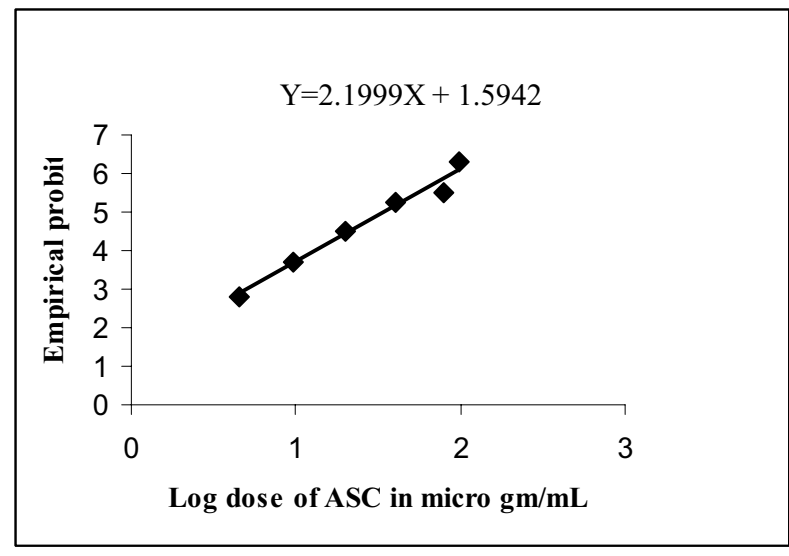

Figure 3: Regression line of log dose of acetone semicarbazone against brine-shrimp nauplii after $24 \mathrm{~h}$ of exposure

harvested in cold $(0.9 \%)$ saline, pooled, centrifuged and re-inoculated into 2 fresh groups of mice $(\mathrm{n}=4)$ as before. No further treatment was done on these mice. On day 5 , they were sacrificed and viable tumor cell count/mouse was estimated.

j) Average tumour weight and survival time: These parameters were measured under similar experimental conditions as stated in the previous experiment. Tumour growth was monitored daily by measuring weight change. The host survival time was recorded and expressed as mean survival time in days and the percent increase of life span was calculated ${ }^{23}$ as follows:

Mean survival time (MST) $=\frac{\begin{array}{l}\sum \text { Survival time (days) } \\ \text { of each mouse in a group }\end{array}}{\text { Total number of mice }}$ Percent increase
of life span (ILS) $\%=\left(\frac{\text { MST of treated group }}{\text { MST of control group }}-1\right) \times 100$

k) Haematological studies: The haematological parameters $v i z, \mathrm{WBC}, \mathrm{RBC}, \mathrm{Hb}$ content and differential counts were determined ${ }^{24-25}$ by standard methods using cell dilution fluids and a haemocytometer. For this purpose, blood was collected from the mouse by tail puncture. Three groups of mice (with $n=4$ ) were used for doses $0.5,1.0$ and $2.0 \mathrm{mg} / \mathrm{kg}$ (i.p.). of the test compound (ASC). Treatment was started after $24 \mathrm{~h}$ of tumour transplantation and continued for 10 consecutive days. 
On day 12, the blood parameters were assayed. Four groups $(n=4)$ of normal mice were taken for the purpose. The blood from the 1st group of mice assayed on day 0 (without any treatment). The $2^{\text {nd }}$ and $3^{\text {rd }}$ groups of mice were treated with ASC at dose $2.0 \mathrm{mg} / \mathrm{kg}$ (i.p.) for 5 and 10 consecutive days respectively and analyzed as before. The mice of $4^{\text {th }}$ group were treated with $2.0 \mathrm{mg} / \mathrm{kg}$ (i.p.) for 10 consecutive days and assayed on day 25 .

l) Determination of the effect of ASC on normal peritoneal cells: Effects of the Schiff base on normal peritoneal cells were determined ${ }^{26}$ by counting the total peritoneal cells and the number of macrophages. Three groups of mice ( $\mathrm{n}=4$ in each) were treated with ASC at doses $0.5,1.0$, and $2.0 \mathrm{mg} / \mathrm{kg}$ (i.p.) for 3 consecutive days and the $4^{\text {th }}$ (untreated) group $(n=4)$ served as the control. After $24 \mathrm{~h}$ of last treatment, each animal was injected with $5 \mathrm{~mL}$ of normal saline $(0.98 \%)$ into the peritoneal cavity and then sacrificed. The intraperitoneal exuded cells and the number of macrophages were counted using a haemocytometer after staining with $1 \%$ neutral red. m) Brine shrimp lethality bioassay: Cytotoxicity of the compound was screened against Artemia salina in a 1-day in vivo assay ${ }^{27}$. For the experiment $3 \mathrm{mg}$ of the compound was dissolved in $0.6 \mathrm{~mL}(600 \mu \mathrm{L})$ of distilled water to get a concentration of $5 \mu \mathrm{g} / \mu \mathrm{L}$ and by serial dilution technique, solutions of varying concentrations such as 5, 10, 20, 40, 80 and $100 \mu \mathrm{g} / \mathrm{mL}$ were obtained. After $24 \mathrm{~h}$ of incubation, the vials were observed using a magnifying glass and the number of survivors in each vial was counted and noted. From these data, the percentage of mortality of the nauplii was calculated for each concentration and the $\mathrm{LC}_{50}$ value was determined using Probit analysis as described in the literature ${ }^{28}$.

n) Statistical analysis: The experimental results were expressed as the mean \pm SEM (standard error of mean). Data were calculated by one way ANOVA followed by Dunnett ' $\mathrm{t}$ ' test using SPSS software version 10.

Table 1: Effect of ASC on EAC cell growth inhibition (in vivo)

\begin{tabular}{|c|c|c|c|c|}
\hline Experiment & Nature of the drug & $\begin{array}{l}\text { Dose } \mathrm{mg} / \mathrm{kg} / \text { day } \\
\text { (i.p.) }\end{array}$ & $\begin{array}{l}\text { No. of EAC cells in mouse } \\
\text { on day } 6 \text { after tumour cell } \\
\text { inoculation }\end{array}$ & $\begin{array}{c}\% \text { of cell growth } \\
\text { inhibition }\end{array}$ \\
\hline $\begin{array}{l}\text { Control (EAC } \\
\text { cell bearing mice) }\end{array}$ & - & - & $(4.03 \pm 0.57) \times 10^{7}$ & ---- \\
\hline Bleomycin & Standard & $0.3 \mathrm{mg} / \mathrm{kg}$ & $(0.42 \pm 0.05) \times 10^{7 * *}$ & 89.57 \\
\hline \multirow[t]{3}{*}{ Acetone semicarbazone } & Synthetic & $0.5 \mathrm{mg} / \mathrm{kg}$ & $(1.66 \pm 0.29) \times 10^{7}$ & 8.80 \\
\hline & & $1.0 \mathrm{mg} / \mathrm{kg}$ & $(1.06 \pm 0.08) \times 10^{7 *}$ & 73.69 \\
\hline & & $2.0 \mathrm{mg} / \mathrm{kg}$ & $(0.65 \pm 0.13) \times 10^{7 * *}$ & 83.87 \\
\hline
\end{tabular}

Number of mice in each case are 6; the results are shown as mean \pm SEM and compared with the control, where significant values are $* \mathrm{p}<0.05$ and $* * \mathrm{p}<0.01$.

Table 2: Effect of ASC on survival time of EAC cell bearing mice

\begin{tabular}{lcccc}
\hline Experiment & Drugs & $\begin{array}{c}\text { Dose } \\
\mathrm{mg} / \mathrm{kg} / \text { day (i.p.) }\end{array}$ & $\begin{array}{c}\text { Mean survival time (Days) } \\
\text { mean } \pm \text { SEM }\end{array}$ & \% Increase of life span \\
\hline Control (EAC bearing mice) & & & $19.83 \pm 0.79$ & \\
EAC+ Bleomycin & Standard & 0.3 & $38.50 \pm 0.76$ & $94.15^{* * *}$ \\
& & 0.5 & $25.83 \pm 0.79$ & $30.25^{* *}$ \\
Acetone semicarbazone & Synthetic & 1.0 & $30.83 \pm 0.47$ & $55.47^{* * *}$ \\
& & 2.0 & $35.16 \pm 0.60$ & $77.30^{* * *}$ \\
\hline
\end{tabular}

Numbers of mice in each experiment were 6; the results are shown in mean \pm SEM and compared with control, where significant values are, ${ }^{*} \mathrm{p}<0.05,{ }^{* *} \mathrm{p}<0.01$ and ${ }^{* * *} \mathrm{p}<0.001$ 
Table 3: Effect of ASC on blood parameters of tumour bearing and normal Swiss albino mice on day 12 of tumour inoculation

\begin{tabular}{|c|c|c|c|c|c|c|}
\hline Experiment & $\begin{array}{c}\mathrm{RBC} \\
\text { cells/mL }\end{array}$ & $\begin{array}{c}\text { WBC } \\
\text { cells/mL }\end{array}$ & $\begin{array}{c}\% \text { of } \mathrm{Hb} \\
\mathrm{gm} / \mathrm{dL}\end{array}$ & $\begin{array}{c}\% \text { of } \\
\text { Lymphocytes }\end{array}$ & $\begin{array}{c}\% \text { of } \\
\text { Neutrophils }\end{array}$ & $\begin{array}{c}\% \text { of } \\
\text { Monocytes }\end{array}$ \\
\hline Normal mice & $(6.11 \pm 0.40) \times 10^{9}$ & $(10.4 \pm 1.2) \times 10^{6}$ & $11.6 \pm 1.2$ & $72 \pm 0.3$ & $23 \pm 0.2$ & $5 \pm 0.65$ \\
\hline $\begin{array}{l}\text { Control (EAC bearing } \\
\text { mice }\end{array}$ & $(2.32 \pm 0.2) \times 10^{9}$ & $(25.7 \pm 0.4) \times 10^{6}$ & $5.0 \pm 0.70$ & $51 \pm 0.65$ & $36 \pm 1.2$ & $13 \pm 0.6$ \\
\hline $\mathrm{EAC}+0.5 \mathrm{mg} / \mathrm{kg}$ & $(2.4 \pm 0.35) \times 10^{9}$ & $(17.0 \pm 0.65) \times 10^{6 *}$ & $10.4 \pm .21^{* * *}$ & $48 \pm 0.54$ & $37 \pm 0.41$ & $15 \pm 0.21$ \\
\hline $\mathrm{EAC}+1.0 \mathrm{mg} / \mathrm{kg}$ & $(3.2 \pm 0.14) \times 10^{9}$ & $(15.0 \pm .31) \times 10^{6^{*}}$ & $10.7 \pm .36^{* * * *}$ & $65 \pm 0.24^{* * *}$ & $32 \pm 0.54^{*}$ & $3 \pm 0.18^{* * * *}$ \\
\hline $\mathrm{EAC}+2.0 \mathrm{mg} / \mathrm{kg}$ & $(4.2 \pm .31) \times 10^{9 * * *}$ & $(13.0 \pm .34) \times 10^{6 * *}$ & 11. $\pm 0.11^{* * *}$ & $69 \pm 0.25^{* * *}$ & $29 \pm 0.45^{* *}$ & $2 \pm 0.54^{* * *}$ \\
\hline
\end{tabular}

Number of mice in each case were 4 ; the results are shown as mean \pm SEM and compared with control (EAC bearing), where significant values are, ${ }^{*} \mathrm{p}<0.05, * * \mathrm{p}<0.01$ and $^{* * *} \mathrm{p}<0.001$

Table 4: Effects of acetone semicarbazone on blood parameters in normal mice on days, $0,5,10$ and 25 at dose $2.0 \mathrm{mg} / \mathrm{kg}$ body weight

\begin{tabular}{lccccccc}
\hline Experiment & Days & $\begin{array}{c}\mathrm{RBC} \\
\mathrm{cells} / \mathrm{mL}\end{array}$ & $\begin{array}{c}\mathrm{WBC} \\
\mathrm{cells} / \mathrm{mL}\end{array}$ & $\begin{array}{c}\text { \% of } \\
\mathrm{Hb}\end{array}$ & $\begin{array}{c}\text { \% of } \\
\text { Lymphocyte }\end{array}$ & $\begin{array}{c}\text { \% of } \\
\text { Neutrophil }\end{array}$ & $\begin{array}{c}\% \text { of } \\
\text { Monocyte }\end{array}$ \\
\hline $\begin{array}{l}\text { Normal mice } \\
\text { Mice treated with }\end{array}$ & 5 & $(6.11 \pm 0.40) \times 10^{9}$ & $(10.4 \pm 1.2) \times 10^{6}$ & $11.6 \pm 1.2$ & $72 \pm 0.3$ & $23 \pm 0.2$ & $5 \pm 0.65$ \\
$\begin{array}{l}\text { Acetone semicarb } \\
\text { azone }\end{array}$ & 10 & $(5.09 \pm 0.82) \times 10^{9 * *}$ & $(6.92 \pm 0.21) \times 10^{6_{* *}}$ & $7.2 \pm 0.19^{* * *}$ & $62 \pm 3.1^{* *}$ & $29 \pm 1.2^{* *}$ & $4 \pm 1.2$ \\
& 25 & $(6.13 \pm 0.54) \times 10^{*}$ & $(9.43 \pm 1.1) \times 10^{6 * *}$ & $11.7 \pm 01.3$ & $71 \pm 2.1$ & $21 \pm 0.92$ & $8 \pm 1.4$ \\
\hline
\end{tabular}

Number of mice in each group were 4; the results are shown as mean \pm SEM and compared with control with normal mice (without treatment) where significant values are, ${ }^{*} \mathrm{p}<0.05,{ }^{* *} \mathrm{p}<0.01$ and ${ }^{* * *} \mathrm{p}<0.001$

Table 5: Effect of the test compound on the enhancement of normal peritoneal cells in mice

\begin{tabular}{lclc}
\hline Experiment & $\begin{array}{c}\text { Dose } \\
\mathrm{mg} / \mathrm{kg}\end{array}$ & $\begin{array}{c}\text { Macrophages } \\
\text { mean } \pm \text { SEM }\end{array}$ & $\begin{array}{c}\text { Total peritoneal cells } \\
\text { mean } \pm \text { SEM }\end{array}$ \\
\hline Control (normal) & - & $(1.67 \pm 0.31) \times 10^{6}$ & $(7.97 \pm 0.40) \times 10^{6}$ \\
Normal + test compound & 0.5 & $(2.15 \pm 0.5) \times 10^{6^{* * *}}$ & $(8.82 \pm 0.34) \times 10^{6 * * *}$ \\
& 1.0 & $(2.35 \pm 0.40) \times 10^{6^{* * *}}$ & $(8.92 \pm 0.44) \times 10^{6 * * *}$ \\
& 2.0 & $(2.57 \pm 0.55) \times 10^{6^{* * *}}$ & $(9.63 \pm 0.43) \times 10^{6 * * *}$ \\
\hline
\end{tabular}

Number of mice in each case were 6 ; the results are shown as mean \pm SEM and compared with normal mice (without treatment), where significant values are, ${ }^{*} \mathrm{p}<0.05,{ }^{* *} \mathrm{p}<0.01$ and $^{* * *} \mathrm{p}<0.001$

\section{RESULTS}

In vivo tumour cell growth inhibition was observed with ASC at various doses $(0.5 \mathrm{mg} / \mathrm{kg}$ i.p., $1.0 \mathrm{mg} / \mathrm{kg}$ i.p., and $2.0 \mathrm{mg} / \mathrm{kg}$ i.p.) per mouse per day. Maximum cell growth inhibition (about $83.87 \%$ ) was found after treatment with $2.0 \mathrm{mg} / \mathrm{kg}$ (i.p.). On the other hand bleomycin at a dose of $0.3 \mathrm{mg} / \mathrm{kg}$ (i.p.) inhibited the cell growth by $89.57 \%$ (Table 1).
A reduction in EAC cell growth as high as $75.06 \%$ was observed, when 6 days treated EAC cells were reinoculated into fresh mice (viable cell counts were performed on day 5).

In vivo, the mean survival time (MST) of the untreated tumour bearing mice was 19.83 days. With the treatment of the ASC, this value increased markably. About $77.30 \%$ enhancement of MST was found at $2.0 \mathrm{mg} / \mathrm{kg}$ (i.p.). Bleomycin at a dose of $0.3 \mathrm{mg} / \mathrm{kg}$ (i.p.) increased the MST value to $94.15 \%$ (Table 2 ). 
The treatment with Schiff base also reduced the rate of tumour growth. It was found to be only $27 \%$ at dose $2.0 \mathrm{mg} / \mathrm{kg}$ (i.p.) after 18 days as against $85.5 \%$ without any treatment. With bleomycin $(0.3 \mathrm{mg} / \mathrm{kg}$, i.p. the growth rate reduced to $21 \%$ in 18 days (Figure 2).

The haematological parameters of both treated and non-treated mice were examined. In EAC cell bearing mice all the parameters such as haemoglobin, WBC, RBC and differential counts (monocytes, lymphocytes, neutrophils) were found to be significantly changed as compared to those of the normal mice. These parameters reverted towards normal values when treated with the compound at dose $2.0 \mathrm{mg} / \mathrm{kg}$ (i.p.). In case of parallel treatment of normal mice, these parameters were found to be slightly changed from normal values, and after 25 days of the initial treatment they were found to be restored to almost normal values (Table 3 and 4). The compound at dose $2.0 \mathrm{mg} / \mathrm{kg}$ (i.p.) also enhanced both the peritoneal cells and the number of macrophages to some extent in normal mice (Table 5).

$\mathrm{LD}_{50}$ value in Swiss albino mice was $30 \mathrm{mg} / \mathrm{kg}$ (i.p.). The brine shrimp lethality bioassay was done to assess the in vitro cytotoxic effect of the compound. Medium lethal concentration $\left(\mathrm{LC}_{50}\right)$ of brine shrimp lethality was found to be $35.35 \mu \mathrm{g} / \mathrm{mL}$ (Figure 3).

\section{DISCUSSION}

The results presented above showed that the compound acetone semicarbazone at dose $2.0 \mathrm{mg} / \mathrm{kg}$ (i.p.) can inhibit cell growth of tumour bearing mice sufficiently, reduce tumour growth rate markedly and increase life span dramatically. All these are considered as very important and promising aspects in justifying the potency of a compound in cancer chemotherapy ${ }^{29}$. One of the major problems usually encountered in cancer chemotherapy is myelosuppression followed by anemia ${ }^{30-31}$ due to the reduction of RBC and haemoglobin contents. This is probably due to the deficiency of iron of haemolytic or myelopathic condition ${ }^{32}$. After treatment with the compound under investigation, all the depleted haematological parameters can be reversed towards normalcy. The host toxic effect of the compound is not very high. In addition, the treatment in normal mice increases the macrophages and peritoneal cells which has also been considered as a very vital event in acquiring self destroying activity of the living being towards cancer cells $^{33}$. Enhancement of macrophages might produce some cytokines such as tumour necrosis factors (TNF) and interleukins inside the peritoneal cavity, which in turn may be responsible for killing of tumour cells ${ }^{34}$. Effect of ASC on viability of EAC cells is found to be reduced significantly. In addition, since $\mathrm{LD}_{50}$ value of ASC is found to be $30 \mathrm{mg} / \mathrm{kg}$ (i.p.) as compared with the dose $(2.0 \mathrm{mg} / \mathrm{kg})$ used during treatment, ASC is expected to be an effective anticancer agent with low toxicity (at doses up to $2.0 \mathrm{mg} / \mathrm{kg}$ ). However, the information obtained from the present investigation is insufficient for ASC to be used as a novel anticancer agent in clinical practice. Many more investigations have to be carried out with this compound and also with its derivatives using various other cancer cell lines and higher animal models, in order to confirm it as a potent anticancer agent.

\section{Acknowledgement}

The authors are grateful to IICB, India, for providing the EAC cells and also to ICDDRB, Bangladesh for supplying the standard mice pellets.

\section{References}

1. Abdullaev F.I., Luna R.R., Roitenburd B.V. \& Espinosa A.J. (2000). Pattern of childhood cancer mortality in Mexico. Archives of Medical Research 31(5):526-531.

2. Pandeya S.N., Sriram D., Nath G. \& Declereq E. (1999). Synthesis, antibacterial, antifungal and antiHIV activities of schiff and mannich bases derived from isatin derivatives and N-[4-(4'-chlorophenyl)thiazol-2-yl] thiosemicarbazide. European Journal of Pharmaceutical Sciences 9(1): 25-31.

3 Jesmin M., Ali M.M., Salahuddin M.S., Habib M.R. \& Khanam J.A (2008). Antimicrobial activity of some schiff bases derived from benzoin, salicylaldehyde, aminophenol and 2, 4-dinitro phenyl hydrazine. Mycobiology 36(1): 7073.

4. Boon R. (1997). Antiviral treatment: from concept to reality. Antiviral Chemistry and Chemotherapy 8: 5-10.

5. Shipman C., Smith S.H., Drach J.C. \& Klayman D. L. (1986). Thiosemicarbazones of 2-acetylpyridine, 2-acetylquinoline, 1-acetylisoquinoline, and related compounds as inhibitors of herpes simplex virus in vitro and in a cutaneous herpes guinea pig model. Antiviral Research 6(4):97-222.

6. Islip J., Closier M.D. \& Neville M.C. (1974). Antiparasitic 5-nitrothiazoles and 5-nitro-4-thiazolines. Journal of Medicinal Chemistry 17(2): 207-209.

7. Islam M.R., Mirza A.H., Huda Q.M.W. \& Khan B.R. (1989). The synthesis of some antitubercular agents, aldehyde thiosemicarbazones and 1,2,3 thiodiazotine derivatives. Journal of the Bangladesh Chemical Society 2:89-95.

8. Dobek A.S., Klayman D.L., Dickson E.T., Scovill J.P. \& Oster C.N. (1983). Thiosemicarbazones of 2-acetylpyridine, 2-acetylquinoline, 1- and 3 -acetylisoquinoline and related compounds as inhibitors of clinically significant bacteria in vitro. ArzneimittelForschung-Drug Research 33(11):1583-1591.

9. Klayman D.L., Scovill J.P., Bartosevich J.F. \& Mason C. J. 
(1979). 2-Acetylpyridine thiosemicarbazones. 2. N4,N4disubstituted derivatives as potential antimalarial agents. Journal of Medicinal Chemistry 22(11):1367-1373.

10. Molla B.S., Rao B.S., Shridhara K. \& Akberali P. M. (2000). Studies on arylfuran derivatives, part IX. synthesis, characterization and biological studies on some mannich bases carrying 2,4-dichlorophenyl furfural moeity. Farmacology 55:338-344.

11. Klayman D.L., Scovill J.P., Mason C.J., Bartosevich J.F., Bruce J. \& Lin A.J. (1983). 2-Acetylpyridinethiose micarbazones,6.2-Acetylpyridine and 2-butyrylpyridine thiosemicarbazones as antileukemic agents. ArzneimittelForschung-Drug Research 33(7):909-912.

12. Ren S., Wang R., Komatsu K., Bonaz-Krause P., Zyrianov Y., McKenna C.E., Csipke C., Tokes Z.A. \& Lien E.J. (2002). Synthesis, biological evaluation, and quantitative structure-activity relationship analysis of new Schiff bases of hydroxysemicarbazide as potential antitumor agents. Journal of Medicinal Chemistry 45(2):410-419.

13. T'ang A., Lien E.J. \& Lai M.M. (1985). Optimization of the Schiff bases of N-hydroxy-N'-aminoguanidine as anticancer and antiviral agents. Journal of Medicinal Chemistry 28(8):1103-1106.

14. Afrasiabi Z., Sinn E., Lin W., Ma Y., Campana C. \& Padhya S. (2005). Nickel (II) complexes of naphthaquinone thiosemicarbazone and semicarbazone: synthesis, structure, spectroscopy, and biological activity. Journal of Inorganic Biochemistry 99(7):1526-1531.

15. Hall I.H., Wong O.T. \& Chapman J. M. (1995). Cytotoxicity of imides-N-alkyl semicarbazones, thiosemicarbazones, acetylhydrazones and related derivatives. Anticancer Drugs 6(1):147-153.

16. Liu M.C., Lin T.S. \& Sartorelli A.C. (1992). Synthesis and antitumor activity of amino derivatives of pyridine-2carboxaldehyde thiosemicarbazone. Journal of Medicinal Chemistry 35(20):3672-3677.

17. Richardson D.R, Sharpe P.C., Lovejoy D.B., Senaratne D., Kalinowski D.S., Islam M. \& Bernhardt P.V. (2006). Dipyridyl thiosemicarbazone chelators with potent and selective antitumor activity form iron complexes with redox activity. Journal of Medicinal Chemistry 49(22):6510-6521.

18. Vogel A.I. (1966). Elementary Organic Chemistry $2^{\text {nd }}$ edition. Part:2 Qualitative Organic Analysis p. 118. Longman Publication, London.

19. Clarke M.T. \& Haynes B. (1975). A Handbook of Organic Analysis, $5^{\text {th }}$ edition p. 117, Edward Arnold publishers, London.
20. Litchfield J.T. \& Wilcoxon F. (1949). A simplified method of evaluating dose-effect experiments. Journal of Pharmacology and Experimental Therapeutics 96: 99113.

21. Sur P. \& Ganguly D.K. (1994). Tea plant root extract (TRE) as an antineoplastic agent. Planta Medica 60:106109.

22. Abbot B.J. (1976). Bioassay of plant extracts for anticancer activity. Cancer Treatment Reports 60:1007-1017.

23. Rusia U. \& Sood S.K. (1988). Medical Laboratory Technology: A Procedure Manual for Routine Diagnostic Tests. Vol. 1: Chapter 10:228. Ed. K.L. Mukherjee, Tata McGraw Hill Comp. Ltd., New Delhi.

24. Mukherjee K.L. (1988). Medical Laboratory Technology. volume 1: pp. 215-280. Tata McGraw Hill Publishers. Company Ltd: New Delhi: pp. 215-280.

25. Hudson L. \& Hay F.C. (1989). Practical Immunology p.26. Blackwell Science Publisher, Oxford, London.

26. Meyer B.N., Ferringni N.R., Putnam J.E., Jacobsen L.B., Nichols D.E. \& Mclaughlin J.L.A. (1982). Convenient general bioassay for active plant constituents. Planta Medica 45:34-39.

27. Finney D.J. (1971). Probit Analysis. p. 333 Cambridge University Press, London.

28. Clarkson B.D. \& Burchenal J.H. (1965). Preliminary screening of antineoplastic drugs. Progress in Clinical Cancer: 1:625-629.

29. Price V. E. \& Greenfield R.E. (1958), Anemia in cancer. Advances in Cancer Research 5:199-200.

30. Hoaglad H.C. (1982). Hematological complication in cancer chemotherapy. Semin Oncology 9:95-102.

31. Fenninger L.D. \& Mider G.B. (1954). Energy and nitrogen metabolism in cancer. Advances in Cancer Research 2: 2229-2253.

32. Barger A. (1981). Medicinal Chemistry, $3^{\text {rd }}$ edition, Volume 2, pp. 2:602-653. John Wiley \& Sons, London.

33. Fernandes D.J. \& Klubes P. (1979). A biochemical and pharmacological study of therapeutic system with 5-fluorouracil plus cyclophosphamide in murine L1210 leukemia. Cancer Research 39: 1396-1404.

34. Lee N.N., Cadman E.C., Michael I.N., Michael C., Joseph R., Bertino Farber L.R.. \& Prosnitz L.R. (1982). Randomized study comparing doxorubicin, cyclophosphamide, vincristine, methotrexate with leucovorin rescue, and cytarabine (ACOMLA) with cyclophosphamide, doxorubicin, vincristine, prednisone, and bleomycin (CHOP-B) in the treatment of diffuse histiocytic lymphoma. Cancer Treatment Report $\mathbf{6 6}$ (6):1279-1284. 